\title{
MLH1 Gene
}

National Cancer Institute

\section{Source}

National Cancer Institute. MLH1 Gene. NCI Thesaurus. Code C18482.

This gene plays a role in DNA mismatch repair. 